Uniwersytet Gdański

\title{
Co nie mieści się w dobrze pojętym republikanizmie. Wybrane narracje republikanizmu w cywilizacji Zachodu. Od czasów antyku greckiego po czasy współczesne
}

\begin{abstract}
Abstrakt:
Przedstawiony artykuł skupia się na pojęciu republikanizmu w perspektywie historii myśli politycznej, od antycznej Grecji do współczesności. Jest w nim poruszony problem odczytywania myśli starożytnej, pojawiaja się nawiązania do Arystotelesa, Cycerona, Machiavellego, Thomasa Hobbesa, Monteskiusza, Carla Schmitta, Quentina Skinnera czy Thomasa Pangle'a. Wszystko to jest odnoszone także do filozofii cywilizacji, $\mathrm{w}$ tym tzw. pięciomianu wartości autorstwa Feliksa Konecznego. Poszukiwane sa w historii filozofii zachodniej różnice i podobieństwa $\mathrm{w}$ rozumieniu tego, jak powinien wyglądać dobrze pojety republikanizm.
\end{abstract}

Słowa kluczowe: republikanizm, cywilizacja Zachodu, antyk, średniowiecze, współczesność, historia myśli, filozofia polityczna

(...) nie masz (...) dla ludzi lepszego sposobu doskonalenia się jak poprzez wiedzę o czynach przeszłości (...) nauka płynąca $z$ historii jest najprawdziwszą szkołą kształcenia i zaprawiania do za- jęć publicznych, a wspominanie cudzych przygód jest najwyraźniejszym i jedynym wskaźnikiem, jak można zmiany losu z godnością znosić ${ }^{1}$.

\section{Wstępne uwagi terminologiczno- metodologiczne}

Staroświeckość podejścia starożytników ${ }^{2}$ oznacza m.in. pewnego rodzaju „nieprzystosowanie do otaczającej moderności" - pozostajacego w ruchu, niewykształconego w swej formie nowoczesnego świata społeczno-kulturowego. Ta pozycja ma wszak swe zalety: Można zachowywać dystans i z perspektywy antycznej spoglądać na niedorzeczne aspekty współczesności ${ }^{3}$.

1 Polibiusz, Dzieje, t. 1, tłum. S. Hammer, Ossolineum - DeAGOSTINI, Wrocław 2005, s. 3.

${ }^{2} \mathrm{Tj}$. osób, które w sporze starożytników $z$ nowożytnikami staja po stronie nowożytnych - zob. np. S. Rosen, The ancients and the moderns, Yale University Press, New Haven 1989.

3 Jedno takie usiłowanie mam już za sobąhttp://janek.uek.krakow.pl/ limes/files/el2(3)2003/rp_limes2(3).pdf. Esej ten ukazał się później w tomie zbiorowym Globalizacja i my, Kraków 2003 - opisywałem wtedy i poddawałem analizie globalizację $z$ perspektywy typologii przyczynowości Arystotelesa. 
Współczesne posługiwanie się wzorcem klasycznego republikanizmu przypomina sytuację podobną: sa to próby zrozumienia czegoś trwałego, pewnego archetypu, który doświadcza coraz to nowych przeobrażeń, aż po zanik określoności słów. Klasyczny ustrój republikański nie przedstawia się (jak zapewne życzyliby sobie konserwatyści) jako szacowna instytucja, istniejacca $z$ dawien dawna, pieczołowicie przekazywana $z$ pokolenia na pokolenie. Najczęściej nawiązania do antycznego modelu republiki sa bardzo selektywne, okrojone i przeobrażone aż nie do poznania. Tak zapewne też być musi. Rzecz w tym, żeby wszakże czerpać inspirację $z$ najlepszego źródła i nie poszukiwać skarbów republikanizmu gdziekolwiek.

Skądinąd jestem zdania, że te „nasze republikańskie opowieści” posiadaja podobna wartość teoretyczno-praktyczna jak przeciętne mity czasów starożytnych, a i to dalece poniżej Baghavatgity czy Talmudu; jest w tym pewna dawka proto-teologii i sporo zupełnie „nienaukowych opowieści o lepszym świecie”, sytuującym się gdzieś poza.

$* * *$

Narracja4 to "opowieść", odtwarzana i rozwijana w ramach czyjejś myśli albo tradycji całej zbiorowości, trwającej wiele pokoleń. Narracja jest określeniem bardziej pojemnym od dyskursu i to mniej rygorystycznym, gdyż w zasadzie rzadko pretenduje do akademickiej naukowości, mimo iż zawiera przestrzeń dla sporów i rozumnego dyskutowania. Ma ona wymiar praktyczny - ma czynić zrozumiałym działanie i je podtrzymywać czy w słabszym sensie uzasadniać. My

4 Por. A. Toynbee, Studium historii. Skrót dokonany przez D. C. Somervella, tłum. i przedm. J. Marzęcki, PiW, Warszawa 2000. posługujemy się tutaj dialogiczno-hermeneutycznym rozumieniem tradycji i nieodłącznie $z$ nią związanej narracji. W ramach tak pojętej tradycji mamy dostęp do stałych punktów odniesienia: zasadniczych pojęć czy wywodów modelowych, typów argumentacji, zbiorów autorytetów, opowieści i ponadto (co ważne) hierarchii wartości. W takiej tradycji, która posiada również swój wariant filozoficzno-polityczny wskazujemy nie tylko na zasadniczo stały zbiór najważniejszych wartości, ale klasyczne sposoby dążenia i znajdowania dóbr, będacych realizacją tychże.

$* * *$

Hermeneutyka uczy, aby zwracać uwage nie tylko, „co się mówi, ale, do kogo kto mówi. Do jakiej publiczności, w jakim kontekście, $z$ jakiej pozycji czy $z$ jakim zamysłem i nastawieniem".

Należałoby stosować te reguły również do narracji republikańskich i tych aspirujacych do teoretyczności, jak i pragmatycznych, będacych pewna odmiana działania, np. przekonywania, pozyskiwania zwolenników czy wreszcie pośredniej afirmacji tożsamości grupowych. W przeciwnym razie możliwości błędnego i powierzchownego wywodzenia wniosków $z$ analizy słów, wypowiedzi, zamiarów i celów danej narracji pozostaje ogromne. Nie bez znaczenia jest, czy mówi pojedynczy autor we własnym imieniu, czy ktoś reprezentujacy pewną zbiorowość zwraca się do przyszłych, aczkolwiek jakoś już wybranych vs. wyobrażonych czytelników. Ponadto mamy wiele odmian wypowiedzi zorientowanych praktycznie, ukierunkowanych na osiaganie takiego czy innego celu. Abstrahowanie od tego wszystkiego rodzi po prostu zamieszanie i chaos.

Wyróżnionym rodzajem opowieści, w intencji byłaby tu „narracja republi- 
kańska", obejmująca afirmację oraz obronę zalet republikańskości klasycznej ${ }^{5}$. Afirmacja ta i obrona oznacza opowiadanie się za pewna tradycja myśli, wartości i działań, w obrębie żywej wspólnoty moralno-cywilizacyjnej, nazywanej łacińska czy Zachodnia. Obrona implikuje odróżnianie i odgraniczanie republikanizmu od jego "podróbek”, zafałszowań i zniekształceń bądź zredukowanych rekonstrukcji. Takie samookreślenie nadal jest wieloznaczne i pełne niedopowiedzen, albowiem należy sobie „przypomnieć” i wyjaśnić te wartości, kluczowe pojęcia, rozumowania czy autorytety założycieli, reformatorów, kontynuatorów (prawdziwych i fałszywych).

\section{Wstępne deklaracje dotyczące odseparowania klasycznego republikanizmu od jego zniekształceń}

Chciałbym uprzedzić, że w klasycznym republikanizmie, za jakim się opowiadam, nie ma miejsca ani dla Locke'a, Hobbesa i z cała pewnością dla Machiavellego. Przeczę, iż jej teoretykiem czy stronnikiem we wczesnym renesansie był Marsyliusz z Padwy, później znowuż raczej - w mej opinii - nie byli stronnikami (i kontynuatorami tegoż): ani Monteskiusz, ani też Rousseau. Nie jest współczesnym tej tradycji rzecznikiem (pełniacym rolę badacza) ani Quentin Skinner ${ }^{6}$, ani John Pocock, ani nawet

${ }^{5}$ Co do mnie osobiście, to nie jestem aż tak zdeklarowanym stronnikiem republiki i republikanizmu. Uważam bowiem, że pośród najszlachetniejszych realizacji ustrojów bywały w różnych czasach i okolicznościach rozmaite jego odmiany: res publica Christiana, zrównoważona monarchia, nawet rzady niektórych faraonów czy cesarzy oceniam jako przyzwoite. Nie podzielam także poglądu Churchilla, iż w praktyce na akceptację zasługuje jedynie demokracja czy liberalne rzady prawa.

${ }^{6}$ Q.Skinner, Wolnośćprzed liberalizmem, tłum. A. Czarnecka, Wyd. Naukowe UMK, Torun 2013. Nie wattpię, że książka Wolność przed liberalizmem
Pierre Manent, z którym (co prawda) łatwiej wszakże byłoby się porozumieć.

Marsyliusz z Padwy traktowany jest w rozmaitych opracowaniach jako kontynuator klasycznej tradycji republikańskiej. Atoli fakt, że odwoływał się on do idei suwerenności ludu, nie czyni go bynajmniej spadkobierca Cycerona ani Arystotelesa. W okresie od Renesansu po Oświecenie, za teoretyków republikanizmu przedstawia się obok Machiavellego również Hobbesa, Monteskiusza, Rousseau i Kanta. Takie ujęcie jest wszakże nadzwyczaj problematyczne, zwłaszcza jeśli nie podkreśla się wręcz kluczowych odchyleń od linii klasycznej. Ta odmienność nowego republikanizmu odnosi się także do Ojców Założycieli Stanów Zjednoczonych, zwłaszcza Hamiltona i Madisona i autorów tzw. Federalisty.

\section{Jakie narracje sa w obiegu?}

Chcąc wstępnie uporządkować istniejące odmiany „narracji republikańskich”, powinniśmy wyodrębnić m. in. najczęściej spotykane gatunki literackie i formy w literaturze przedmiotu znajdujemy:

- historie myśli politycznej, kładące nacisk na rzetelność ustaleń faktograficznych oraz wiarygodność źródeł;

- historie idei czy pojęć;

- wizjeliteracko-artystyczne, np.dramaty Szekspira;

- dzieje filozofii politycznej.

to publikacja potrzebna i pożyteczna, przede wszystkim dlatego, że pozwala zdystansować od kłamliwej identyfikacji sprawy wolności $z$ liberalizmem. Jednakże zawiera ona szereg nieścisłości oraz zniekształceń klasycznej tradycji republikańskiej. Niezależnie od tego, iż jej Autor używa innych określeń, jak np. „neorzymska teoria wolnych obywateli" i od tego, że zakreśla on sobie ograniczone zadanie opisania nowego republikanizmu w posthobbesowskiej Anglii, zawiera wiele twierdzeń wątpliwych a uporczywie ponawianych. 
Dodałbym $^{7}$ do tego zbioru ponadto wielkie syntezy, operujace na materiale historycznym, dostarczanym przez wszystkie powyższe odmiany narracji - syntezy historiozoficzno-cywilzacyjne, czyli filozofie cywilizacji ${ }^{8}$.

Odnotowujemy też pewien rodzaj współpracy i wzajemnego oddziaływania pomiędzy kilkoma subdyscyplinami: między tzw. historia idei, historia doktryn polityczno-prawnych, historia polityczna i myśli politycznej, historiami filozofii prawa i filozofii politycznej oraz szeroko rozumiana filozofia polityki ${ }^{9}$. Dyscypliny historyczne skupiaja się na rekonstrukcji wydarzeń oraz głoszonych koncepcji, lecz niejako „zahaczajacc” o zagadnienia $z$ filozofii polityki, mają swój twórczy wkład w tę dyscyplinę, wkład,

\footnotetext{
7 Jeszcze innym dogodnym sposobem pogrupowania zbioru narracji republikańskich mogłoby być wskazanie konkretnie zaistniałych historycznie wspólnot cywilizacyjno-politycznych, które traktowane były i sa jako udatne „przybliżenie” do modelu republiki; tu $\mathrm{w}$ grę wchodza greckie państewka-miasta, jak Sparta i Ateny, Rzym okresu republikańskiego, republika renesansowej Wenecji czy Florencji itp.

${ }^{8}$ Również A. Toynbee wyróżnia aż trzy typy narracji, występujące $\mathrm{w}$ związku $z$ filozofią cywilizacji. „Przyjmuje się powszechnie, że stwierdzanie i rejestrowanie faktów jest technika badań historycznych i że zjawiskami w zakresie tej techniki są społeczne zjawiska cywilizacji; że wyświetlanie i formułowanie praw ogólnych jest technika nauki i że w badaniach nad ludzkim życiem nauka taka jest antropologia, a zjawiskami w zakresie techniki naukowej sa społeczne zjawiska społeczności pierwotnych; i wreszcie, że fikcja jest technika dramatu i powieści, a zjawiskami w zakresie tej techniki sa osobiste relacje międzyludzkie. Wszystko to można w istotnych rysach znaleźć w dziełach Arystotelesa”. Zob. A. Toynbee, Studium historii. Skrót dokonany przez D.C. Somervella, tłum. i przedm. J. Marzęcki, PiW, Warszawa 2000, s. 56 i 58; brytyjski teoretyk zauważa, że „historia zajmuje się niektórymi, ale nie wszystkimi faktami ludzkiego życia; $z$ drugiej zaś strony, poza rejestrowaniem faktów, historia ucieka się również do fikcji i czyni użytek z praw".

9 Która zajmuję się sam, nazywając ją filozofia cywilizacji.
}

który niekiedy wiedzie do zniekształcenia zarówno prawdy historycznej, jak i uchybień w odtwarzaniu dynamiki wywodów filozoficznych.

\section{Czego się wystrzegać? Fałszywe desygnaty}

Poszerzając zanadto pojęcie republikanizmu - jako przeciwieństwa wszelkiej władzy arbitralnej - współcześni badacze niekiedy (Quentin Skinner) zaliczają do tradycji republikańskiej myślicieli pozostających wręcz na antypodach klasycznej myśli republikańskiej. I tak np. Marsyliusz z Padwy niesłusznie odczytywany jest jako kontynuator Stagiryty i klasycznej tradycji republikańskiej. Fakt, że odwoływał się on do idei suwerenności ludu, nie czyni go bynajmniej spadkobierca Cycerona ani Arystotelesa. Co więcej, to Marsyliusz obok Machiavellego utorowali ścieżki myślowe Hobbesa, Monteskiusza, Rousseau i Kanta, którzy może mają wkład do republikanizmu, lecz w jego domenie niemajacej z klasyczną wiele wspólnego. Takie ujęcie jest zdecydowanie problematyczne, zwłaszcza jeśli nie podkreśla się wręcz kluczowych odchyleń od linii klasycznej. Ta odmienność „nowego republikanizmu” odnosi się także do Ojców Założycieli Stanów Zjednoczonych, zwłaszcza Hamiltona i Madisona i autorów tzw. Federalisty.

„Rządy prawa, przeciwstawność władzy arbitralnej, zwłaszcza monarchicznej" - to kryteria nader nieprecyzyjne i nieprzekonywujące. Trzeba więc się zgodzić ze Stawrowskim, gdy pisze, iż „najbardziej dziś rozpowszechnione rozumienie republiki to po prostu przeciwieństwo monarchii. Dlatego też państwa, w których władzę sprawuje ktoś inny niż król, bywają nazywane republikami, niezależnie od zasadniczych różnic, co do ich kształtu ustrojowego. W tym sen- 
sie miały do tego miana prawo nie tylko Republika Francuska, ale równie dobrze Republika Weimarska, czy nawet Zwiazek Socjalistycznych Republik Sowieckich".

Mamy oczywiście mnóstwo w istocie mylaccych (czy fałszywych) desygnatów swobodnie używanego terminu republi$k a$, skoro słyszeliśmy o Chińskiej Republice Ludowej, „republika” być miało każde składowe państwo ZSRR ${ }^{10}$, łącznie $z$ PRL-em; nie w tym samym znaczeniu używa się podobnych określeń, jak Res Publica Christiana, Republika Francuska czy Mongolska albo republiki islamskie; Trudno wskazać jakiś wspólny mianownik dla tych nazw własnych.

Dygresja: Teokracje - jednowladztwa - demokracje i republiki w kontekście cywilizacyjnym. Kwestie ustrojowe w odmiennych cywilizacjach i w których z nich ustrój republikański nie jest możliwy ${ }^{11}$.

Gdy powołamy się na ustalenia $F$. Konecznego, to jasne się staje, iż np. w cywilizacji bizantyjskiej republika nie jest możliwa; podobnie maja się rzeczy w innych cywilizacjach, gdzie ustroje rodowe starego typu, zapewniajace prymat zbiorowości nad jednostkami - a tak jest w cywilizacji turańskiej, bramińskiej, arabskiej - bardziej złożone konstrukcje ustrojowe, jak ustroje mieszane, oparte na trójprawie i swobodach samorzadowo-obywatelskich, nie moga się rozwinacć.

W kontekście cywilizacyjnym niejednokrotnie okazać się musi, że tzw. repu-

10 Jeśli zarówno Rosja dawniejsza, jak i współczesna byłaby (jak chciał Koneczny) rozpięta pomiędzy cywilizacja turańska oraz bizantyjska, to żadnego republikanizmu tam szukać nie należy, gdyż w tych cywilizacjach struktury republikańskie sa wykluczone.

11 Ustroje rodowe, trójprawo, iloczyn społeczny, stosunek władz politycznych i duchowych autorytetów. bliki islamskie to raczej „zamaskowane” teokracje lub arystokracje, a tzw. Republiki (zd-)Radzieckie to nowa forma tyranii, USA to najprawdopodobniej imperium o osobliwym ustroju zmieszanym: prezydencko-republikańskim.

\section{Zróżnicowanie republikanizmów, narracji prorepublikańskich a nowożytna tradycja republikańska}

Po tych uwagach wprowadzajacych, możemy powiedzieć, że o ile klasyczny republikanizm tworzy określona tradycję republikańska, $z$ charakterystycznymi dla siebie odmianami narracji (kluczowych pojęć, np. cnót obywatelskich, aktywnych rządzonych i podwyższonych kwalifikacji elit, dobra powszechnego, wysokich standardów moralnych i dóbr samoistnych), to luźno zakreślany tzw. nowy republikanizm, a szczególnie ten post-Machiavellowski, w tej tradycji się nie mieści.

Nowożytna tradycja republikańska zdecydowanie różni się od klasycznej antycznej grecko-rzymskiej, spod znaku Arystotelesa i Cycerona. Niemniej jednak część współczesnych opracowań dotyczacych republikanizmu operuje uproszczeniem, sugerując zasadniczą zbieżność czy wręcz ciagłość pomiędzy obrazem republiki myślicieli przednowoczesnych i nowoczesnych. Wprawdzie klasyczny republikanizm nie był jednolita i rozbudowana koncepcja filozoficzna, to jednak posiadał sprecyzowany rdzeń znaczeniowy. W swoich pismach rzecznicy republikanizmu eksponowali zalety ustroju republikańskiego i poddawali krytyce inne formy ustrojowe (przede wszystkim tyranię, jednowładztwo w ogóle oraz demokrację).

W republikanizmie nowoczesnym mamy oczywiście wiele - bardziej czy mniej przeciwstawnych nawet - odmian 
czy nurtów. Do nurtu republikanizmu liberalnego (nazywanego ${ }^{12}$ obywatelskim humanizmem), jak i do nowoczesnej filozofii politycznej, poważną część owego novum wnieśli Machiavelli i Hobbes.

Obu myślicieli wiele łączy, a ich przemożny wpływ na nowożytne nurty republikanizmu dalece przekracza czas i miejsce ich życia oraz kraje pochodzenia. Wszakże istotne są również różnice między nimi. Jedną $z$ głównych jest ich odmienny stosunek do wojny i pokoju. Łaczy ich antropologiczny pesymizm, sceptycyzm względem wiary oraz naturalizm.

Charakterystyczne dla obu jest to, iż patrza na człowieka jako na cząstkę świata przyrodniczego, ujmowanego w kategoriach immanentnych mechanistycznych zależności. To pociaga za soba odrzucenie klasycznej tradycji prawa naturalnego, odejście od antycznej czy chrześcijańskiej etyki dzielności i instrumentalne traktowanie moralności jako takiej. Ściśle rzecz biorac: obaj mocno dystansują się od klasycznego republikanizmu, o korzeniach grecko-rzymskich, obaj odrzucaja klasyczna etykę cnót.

Pozostaje również mocno dyskusyjne, czy można ich uznać bez zastrzeżeń za zwolenników nowoczesnego republikanizmu, ponieważ Hobbes w zasadzie opowiadał się za monarchia absolutna, a Machiavellego predylekcja dla ustroju republikańskiego jest nader ambiwalentna ${ }^{13}$. Nie zmienia to faktu ich przemożne-

12 Raczej myląco.

13 Pewna komplikacje stanowi fakt, że cesarstwo (w tym i cesarstwo rzymskie) nie jest zwyczajna odmiana, tylko powiększonej, ekspansywnej monarchii; jest bowiem taka jej odmiana, która zastępuje upadająca czy już upadła republikę; pewnym przetworzeniem takiego "hybrydowego ustroju”, gdzie mamy „zmieszanie” jednowładztwa oraz jakichś elementów republikańskich; ma to miejsce np. we współczesnych ustrojach $z$ silną władzą prezydencka. Zob. na ten temat ciekawe rozważania P. Manenta, rozdz. I: Rzym i Grecy, w: idem, Prze- go wpływu na losy i przeobrażenia nowożytnego republikanizmu, nie wyłaczajac Ojców Założycieli Stanów Zjednoczonych, jak i republikanizmu liberalnego.

\section{Myś1 „republikańska” czy pastiszowa retoryka Machiavellego?}

Myśl republikańska Machiavellego, podobnie jak wiele fragmentów jego książek w ogóle, posiada cechy mowy czysto retorycznej ${ }^{14}$. Dlatego trzeba je odczytywać $z$ ostrożnością i podejrzliwością, żeby nie dawać się wprowadzić w błąd.

Machiavelli wbrew historykom rzymskim (takim jak Tacyt i Tytus Liwiusz) podejmuje się obrony zarówno reputacji ludu, jak i rządzących, wywodzących się z ludu. Przekonuje, iż jedni i drudzy bywaja rozmaici, trafiaja się i lepsi i gorsi. Zostajac władcami bywaja zmienni i niewdzięczni, nie inaczej jak rzązacy pochodzenia nie ludowego. W ten sposób Florentczyk poniekad przygotowuje znany (aczkolwiek raczej fałszywy) aforyzm liberałów, o tym, że wszelka władza korumpuje wszystkich jednakowo.

Tym, co Machiavelli ignoruje i pomija, jest hamulec moralny, doświadczenie sacrum (czy tabu) oraz bojaźń przed Bogiem i strach przed wynaturzeniem. To pominięcie ${ }^{15}$ otwiera Machiavellemu

miany rzeczy publicznej. Od Aten do całej ludzkości, a szczeg. tzw. Moment Cyceroński, tłum. W. Dłuski, Wyd. Europejskie Centrum Solidarności, Gdańsk 2014.

${ }^{14}$ Czyli nie należy jej brać dosłownie i na poważnie.

15 Także i Polibiusz podziwiał rzymską republikę, a ponadto wielkość jej mierzył zdolnościa odnoszenia sukcesów w podbojach, umiejętnościa panowania na rozległym terytorium: „Rzymianie, którzy (...) cały niemal świat uczynili sobie poddanym, wznieśli swoje panowanie do takiej wyżyny, że dawniejsze wieki nie mogą się z nią zmierzyć, a późniejsze nie potrafia jej przekroczyć" (Polibiusz, Dzieje, op. cit., s. 4). Wskazujac na nadzwyczajne powodzenie Rzymian w podbijaniu ówczesnego świata, Polibiusz powiada, że jak dotychczas 
(i jego kontynuatorom) drogę ku sekularyzacji polityki i światu bez Prawa Natury i bez Bożej Opatrzności. Wywód ten harmonizuje $z$ moja teza o paradoksalnym ideale nowego władcy Machiavellego jako "dzielnym tyranie”. Obecnie dodałbym, iż Florentczyk „realista” w ten sposób, niejako przygotował intelektualny grunt pod nowoczesne tyranie, czyli rządy nad masami przywódców w rodzaju Adolfa Hitlera czy oligarchicznej „elity nowego typu", które znamionuje mentalność pospólstwa wyzbytego hamulców moralnych.

\section{Zasadnicze różnice pomiędzy Machiavellim a Arystotelesem}

Powiedzmy wprost: różnice pomiędzy Machiavellim a Arystotelesem sa tak ogromne, że niewłaściwe jest używanie tego samego terminu w odniesieniu do ich stanowisk. Podobna postawę zorientowana na rozdzielanie pozornie zbieżnych pozycji w odniesieniu do Hobbesa i angielskiej tradycji republikańskiej dokonał Rahe, względem zaś Machiavellego - Mansfield.

Machiavelli rozumował na temat państwa w kategoriach posesywno-własnościowych; już sam ten fakt wystarcza, aby jego symulowany republikanizm uznać za czysto retoryczny lub hybrydo-

„nikt o tym nie pomyślał, żeby zbadać powszechny i ogólny związek faktów historycznych"; własne czasy ocenił on jako bezprecedensowe, albowiem, „choć (...) Los przynosi wiele nowych rzeczy i stale w życiu ludzkim popisuje się swą siłą, to przecież istotnie nigdy jeszcze takiego nie dokonał dzieła, ani takiego nie urzadził widowiska, jak za naszych czasów. Tego dostrzec nie można u tych, którzy historię pisza po kawałku" (por. Polibiusz, Dzieje, op. cit., s. 6). Widoczne jest u Polibiusza nastawienie badawcze większych jednostek analizy świata ludzkiego, czyli właściwie cywilizacji. W odróżnieniu od Machiavellego grecki historyk nie relatywizuje wartości moralnych, nie głosi pochwały siły materialnej jako takiej, bez względu na wszystko inne. wy. Jak zauważył Mansfield, sztuka rządzenia państwem (arte dello stato), o której mówi, jest uniwersalną umiejętnościa „utrzymywania osobistej dominacji”. Państwa, wedle zwrotów Machiavellego, sa „zdobywane czy uzyskiwane [acquired]" i „staja się [w ten sposób] czyjąś, osobista własnością".

Zasadnicze znaczenie partykularnych korzyści (acquisition) w Il Principe oraz Discorsi pozostaje utrzymane. Ich autor zachowuje postawę neutralności względem wyboru pomiędzy republikami oraz pryncypatami, czyli przypadkami jednowładztwa. Oczywiście znamy rozliczne wypowiedzi Florentczyka wychwalające republiki jako ostoje wolności. Mamy jednak wiele powodów, żeby odczytywać je jako czysto retoryczne. Wprawdzie głosił on, iż dobra wspólnego „nie da się dostrzec, gdzie indziej jak [jedynie] w republikach", ale owo dobro polega - u niego - na „ucisku nielicznych, ze strony wielu, a podleganie podbojom ze strony republik", które zabiegaja o owo dobro wspólne (łącznie $z$ wolnościa dla siebie), „stanowi [wedle jego własnego wyrażenia] najgorsza niewolę". Innymi słowy, podboje republikańskie sam autor Discorsi uznaje za najgorsze.

Zatem opozycja między pryncypatem a republika, u Machiavellego, to opozycja między dwoma partykularyzmami: między egoizmem indywidualnym i zbiorowym. Preferencja dla republikańsko-demokratycznej polityki przed niedemokratyczną u Machiavellego jest względna i określona właściwie przez konieczność, nie zaś wybór ${ }^{16}$. Stąd wniosek, iż opowie-

16 Tu może należałoby „ustapić nieco pola” realistom post-Machiavellowskim, gdyby uznać, że rzeczywisty stan instytucji i obyczajów republikańskich jest $\mathrm{w}$ ruinie, że korupcja wiedzie do przemocy i anarchii, wówczas opowiadanie się za mniejszym złem, podyktowanym koniecznościa, można by usprawiedliwić, choć tylko na zasadzie wyjątku od reguły i pod presja katastrofalnej alter- 
dzenie się przezeń za podyktowane jest raczej względami instrumentalnymi, tj. koniecznościa zachowania własnej pozycji władczej. $Z$ tego należy zaś wnioskować, że nie jest on żadnym republikaninem $z$ przekonania, ni florenckim patriota, który ukrywał się, do czasu, przed groźnymi jednowładcami $z$ rodu Medyceuszy ${ }^{17}$.

Fakt zaprojektowania i powołania milicji ludowej przez Machiavellego nie dowodzi, iż był on wielkim patriota florenckim, ani że kochał ojczyznę republikańską bardziej niż swą duszę ${ }^{18}$. „Jasnowidztwo”, co do rzeczywistych zamiarów i motywów i wypowiedzi i czynów Florentczyka u Virolego jest wysoce zastanawiające. Powtarzaja się frazesy w rodzaju „widzimy wyraźnie"19, „dowiódł swojego całkowitego oddania Republice”, „dowiódł, że ani więzienie ani tortury nie uczyniły zeń innego człowieka"; nie stało się tak, gdyż od dawna był cyniczny, bez charakteru, istny stronnik „niskiego realizmu ${ }^{20}$; Viroli „streszcza” wypowiedzi Machiavellego, zamiast je cytować: „kto dąży do urzeczywistnienia szczytnego zadania - wyzwolenia narodu (...), zaprowadzenia pokoju tam, gdzie panuje

natywy. Jednakże do takiej „logiki mniejszego zła” zniechęca okoliczność, że we współczesnej walce między partiami na co dzień używa się tego rodzaju „retoryki konieczności”, przedstawiając rządy konkurentów jak katastrofę i najgorsze zło.

17 Co sugerował np. Rousseau.

18 Viroli objaśnia słowa Machiavellego: „Kocham messera Francesca Guicciardiniego, kocham ojczyznę bardziej niż własną duszę", tłumacząc, że oto "padły słowa, które zawsze nosił w sercu”, mimo iż wiedział, że takie powiedzenie „we Florencji było zwrotem obiegowym” od XIV wieku. M. Viroli, Usmiech Machiavellego. Biografia. tłum. K. Żaboklicki, wyd. W.A.B., Warszawa 2006, s. 302.

${ }_{19}$ M. Viroli, Uśmiech Machiavellego, op. cit., s. 104 .

${ }^{20}$ M. Viroli, Uśmiech Machiavellego, op. cit., s. 168. „Niski realizm” - to moje określenie: zob. Koncepcja cnót politycznych Machiavellego na tle elementów klasycznej etyki cnót, wyd. UG, Gdańsk 2007. anarchia i despotyzm - ten nie powinien się obawiać opinii okrutnika czy skapca, tylko robić to, co konieczne, aby osiagnać cel"21. Viroli nadzwyczaj swobodnie, żeby nie rzec frywolnie, postępuje $z$ tekstami Machiavellego i to wielokrotnie ${ }^{22}$.

Kategoriami nadrzędnymi względem republiki czy księstwa, wolności czy zniewolenia sa u Florentczyka nie Patria, lecz Konieczność, Fortuna oraz akwizycja, czyli zabezpieczenie interesów materialnych. Stąd nie może być rzeczą zaskakująca, że zdegenerowany pseudorepublikanizm Machiavellego integralnie powiazany został $z$ imperializmem i militarna lub ekonomiczna agresja czy wyzyskiem. „Umiłowanie ludu, wolność republikańska" przeobrażaja się, więc tu w użyteczne frazesy. $Z$ takim „umiłowaniem ludu” mielismy do czynienia w sowieckim komunizmie oraz w Polsce PRL-u.

\section{Oddziaływanie Machiavellego oraz Hobbesa- w opozycji do klasycznej tradycji}

Przejdźmy do wpływów Thomasa Hobbesa. Jak zauważył Rahe, myśl polityczna Hobbesa wychodzi $z$ odrzucenia przez Machiavellego społecznej natury człowieka oraz rozumu praktycznego czy moralnej wyobraźni, majacych podsta-

${ }^{21}$ M. Viroli, Uśmiech Machiavellego, op. cit., s. 192 .

${ }^{22}$ Podobne „jasnowidzenie" wieńczy cała książkę, gdy Viroli najpierw przypomina, iż słynne „Wezwanie do skruchy” (Esortazione..., przypisywane Machiavellemu) to po prostu wypełnienie zwyczaju (u jednego bractw świeckich chrześcijan) układania tekstu pokutnego odczytywanego w czasie Wielkiego Postu. Po czym powiada, że owo Esortazione „zlepek retorycznych zwrotów, parafraz i cytatów z Psalmów i Nowego Testamentu, a więc tekst pisany na zamówienie, jak wiele innych (...), które wyszły spod jego pióra" (Uśmiech Machiavellego, op. cit., s. 306). Skąd autor Uśmiechu... czerpie pewność, że tym razem „frazesy” nie wyrażają tego, co Machiavelli naprawdę myślał i odczuwał? Trudno zgadnaćc! 
wowe znaczenie w klasycznym republikanizmie od Arystotelesa do Cycerona. Hobbes wszakże inaczej niż Machiavelli - dość osobliwie - usiłując zapobiec religijnym przyczynom wojen, wyposaża suwerennego władcę $\mathrm{w}$ prawo narzucania również obowiazującej doktryny religijnej. Rządzący miał być arbitrem i sędzia, gwarantem pokoju wewnętrznego w państwie. Aby zagwarantować długotrwały pokój, Hobbes odwołuje się do przymusu i zastraszenia. Uśmierzając $\mathrm{w}$ ten sposób wewnętrzne niepokoje, de facto uniemożliwia swobody obywatelskie, bez których tradycyjny republikanizm nie może istnieć.

I Machiavelli, i Hobbes mieszcza sie w etosie plebejskim, kładac nacisk na pragnienia bezpieczeństwa materialnego u ludu oraz chęć dominowania ze strony mniejszości ${ }^{23}$. Dla Machiavellego podbój, konflikt i wojna sa czymś „naturalnym”, czego nie pozwala uniknąć Konieczność i ludzka kondycja niedostatku. U Hobbesa zaś, tego rodzaju „stan natury” miałby być przezwyciężony przez pakt społeczny, na straży którego postawiony zostal suweren, będący zarazem gwarantem pokoju w relacjach międzypaństwowych. Element ludowo-republikański u Hobbesa posiada inne zabarwienie: pomyślność rządzonych ma być wynikiem ich pracowitości, rozwoju przedsiębiorczości $i$ handlu. Machiavelli materialna pomyślność ludu projektował zapewniać na drodze podboju militarnego i idącej w ślad za nią eksploatacji podbitych ludów.

Republikanizm klasyczny posiadał charakter ekskluzywny, było w nim miejsce

23 Jednak Hobbes zamiast zapanować nad ludnościa podstępem i sprytnym oszustwem (pozyskaniem ludu, na modłę nowego księcia-władcy), woli raczej lud rozbroić, aby zawczasu uniknać tarć, tumultów i wewnętrznych napięć. na rywalizację i dążenie do wyróżniania się, także w staraniach o zasługi publiczne, czyli dobro wspólne całej społeczności politycznej. Hobbes zaś, przeciwdziałając domniemanej możliwości „powrotu do dzikiego stanu natury", upiera się przy swoim antywolnościowym zrównaniu poddanych względem suwerena.

\section{Wolność republikańska i rządy prawa}

Nie lekceważąc systemów instytucjonalnych zabezpieczeń przed arbitralnościa władzy politycznej i tradycji wychodzacej od trójpodziału władz autorstwa Monteskiusza, chcemy powiedzieć, że zarówno nurtom badań idącym w kierunku sojuszu z liberalnym indywidualizmem (skłaniajacym się ku depolityzacji obywateli), jak i republikanizmu zbliżajacego się do komunitaryzmu, można $z$ perspektywy stanowiska klasycznego republikanizmu wiele wytknać i zarzucić. Było to udziałem części przedstawicieli szkoły Leo Straussa. Mam na myśli Mansfielda, Thomasa Pangle'a czy w Polsce Pawła Kłoczowskiego.

Trzymając się tradycji Arystotelesowskiej, nie powinniśmy pomijać kryterium aksjologiczno-duchowego, inaczej popadamy $\mathrm{w}$ materialistyczny ogląd świata ludzkiego; wiele zależy od tego, jaki wybieramy rodzaj opisu i typ nadrzędnego metajęzyka ${ }^{24}$.

Dobrze uporzadkował kluczowe pojęcia Arystotelesowskiego republikanizmu Paweł Kłoczowski.

${ }^{24}$ Nie jest całkiem oczywiste, czy Voegelin i jemu podobni „spirytualiści - platonicy - chrześcijanie" mogą wyrażać swe stanowiska w języku ustrojów politycznych $\mathrm{w}$ ich najprostszych podzialach? 


\section{Jak rozumiem model klasycznego republikanizmu?}

Wedle Stagiryty należy odróżniać element rzadzacy (archont) i rzadzony (archomenon). Kwestia ustroju to kwestia "rodzajów” władzy, rządzących i rządzonych. Pierwszym i najistotniejszym jest kryterium celowe ${ }^{25}$ : Jaki jest cel władzy? W imię czego rządzący dzierżą władzę? Co jest źródłem ich godności?

Jeśli rządy sprawowane są „dla wspólnej korzyści i wspólnego dobra zarówno rządzacych, jak i rządzonych", to wynika stąd podział na „ustroje właściwe i zwyrodniałe"; w zwyrodniałym ustroju rządzący „rządzą dla własnej korzyści, a nie dla korzyści wspólnej”; a takie rzady sa wszak „despotyczne, [podczas gdy] państwo jest społecznością ludzi wolnych"26.

Cele ustroju bywaja bezwzględne i względne: „Demokracja stawia sobie za cel wolność, oligarchia - bogactwo, arystokracja - sprawy wychowania i praworządności, tyrania bezpieczeństwo tyrana”27. „Drugie kryterium [podziału ustrojów] ma charakter formalno-prawny. Tożsamość ustroju rozpoznajemy przez formę władzy naczelnej (...): albo decyduje jednostka, albo elitarna mniejszość, albo większość" 28 .

25 Jeśli to kryterium pomijane albo pomniejszane, to nawiązania do klasycznej republikańskości zaczyna być mocno watpliwe.

26 Polityka, 1279a; por. P. Kłoczowski, Bitwa ksiażek. Konfrontacja Arystotelesa $z$ nowożytna filozofia polityczna, Wyd. Księgarnia Akademicka, Kraków 2007, s. 135.

27 Retoryka, 1366a 5; por. P. Kłoczowski, op. cit., s. 136 .

28 Występuje tu analogia $z$ władza ojcowska - paternalizm („dzieci oczekuja od ojca troskliwej opieki, ojciec od nich szacunku i posłuszeństwa. Relacje między mężem a żona przypominają ustrój arystokratyczny (...). Wreszcie stosunek koleżeński łączacy braci przywodzi na myśl demokracje (...) równość i podobieństwo charakterów rodzi braterstwo"). Jednakże należy pamiętać, że na „samym
„Z połączenia kryterium celowego i formalnego powstaje podział na sześć ustrojów, trzy właściwe... i trzy zwyrodniałe"29:

- monarchia

- arystokracja

- politeja

- demokracja

- oligarchia

- tyrania

Z perspektywy „kryterium formalnego ważnym czynnikiem różnicującym ustroje sa także urzędy specyficzne dla danego ustroju, ich zadania, rola w systemie władzy oraz sposoby [ich] obsadzania" ${ }^{30}$ :

- kto obsadza,

- z jakiego ośrodka, czy z uprzednio wytypowanej listy,

- w jaki sposób.

W politejach mamy do czynienia w tym zakresie $z$ kombinacjami rozmaitych sposobów ${ }^{31}$.

Kryterium materialne ma charakter indukcyjno-historyczny. Pytamy [bowiem] o tworzywo (hyle) z którego powstał dany ustrój, pytamy o podłoże społeczne, ekonomiczne, demograficzne i geograficzne. W ten sposób uzyskujemy „rozmaite odmiany w ramach poszczególnych ustrojów (...). Materią ustrojów jest przede wszystkim specyfika ludności. W grę wchodzi: jej liczba, podział - wolni czy niewolnicy, rzemieślnicy, handlujący kupcy, pracownicy najemni, żołnierze, kapłani, bogaci czy biedni, wykształceni czy nie"32. Konflikt biedni bogaci ma często znaczenie zasadnicze $\mathrm{e}^{33}$.

początku Polityki Arystoteles przestrzega przed identyfikowaniem władzy domowej $z$ polityczna, sa one bowiem zupełnie różne w swoim rodzaju (P, 1252a)".

${ }^{29}$ P. Kłoczowski, op. cit., s. 137.

30 Ibidem, s. 139.

31 Ibidem, s. 141.

32 Ibidem, s. 142.

33 Istnieje pewne podobieństwo pomiędzy klasyfikacją ustrojów a klasyfikacja gatunków zwie- 
Najlepsza oligarchia daje się urzadzić w sytuacji, gdy większa liczba obywateli posiada [chociaż] mały majątek. A gdy jest najlepsza, to zbliża się do najlepszej odmiany demokracji i ma szansę się $z$ nią zmieszać, dając wyższą formę ustroju, a mianowicie politeję. Politeja jest osiagalna jedynie w społeczeństwie stosunkowo zamożny ${ }^{34}$. Gorsza jest sytuacja, gdy jest mniej bogatych, lecz majacc większy majątek, to oni obsadzają urzędy przez kooptację.

Jeszcze gorsze sa rzady nielicznych oligarchów, bardzo bogatych, którzy decyduja o obsadzie urzędów swoimi ludźmi; najgorsza jest zaś oligarchia, w której rządzi nie prawo, lecz samowola wielmożów. Taka oligarchia, podobnie jak najgorsza demokracja, nie różni się zbytnio od tyranii ${ }^{35}$.

Mamy jeszcze czwarte kryterium - kryterium skuteczności: na ile dany ustrój zbliża się do tego najlepszego bezwzględnie albo do względnie najlepszego przy danych uwarunkowaniach. Arystoteles nie gorzej od Machiavellego zdawał sobie sprawę, że ustroje idealne sa tak bardzo wymagające, iż właściwie niemożliwe do praktycznej realizacji; sa więc one jedynie ostatecznym pułapem aspiracji, przedmiotem marzeń, życzeń i modlitwy; moga być drogowskazem dla poszukiwania jakiegoś przybliżenia doń.

Kłoczowski, przez wzgląd na duże zróżnicowanie wszystkich odmian ustrojów, w rozumieniu Arystotelesa, zapro-

rząt. Ilość części składowych, organy, narządy, różne ich rodzaje oraz typy wykonywanych ruchów; po uwzględnieniu tych wszystkich czynników mamy ogromna liczbę ukonkretnionych ustrojów politycznych (P. Kłoczowski, op. cit., s. 143). Demokracja będzie zawsze albo rolnicza, pasterska, wiejska lub wielkomiejska. I „demokracje i również oligarchie oscyluja między formami bardziej nomokratycznymi i bardziej woluntarystycznymi. Również i tu sprawy majątkowe odgrywaja kluczowa rolę".

${ }_{34}$ Por. P. Kłoczowski, op. cit., s. 145.

35 Ibidem, s. 146. ponował ciekawy "gradualistyczny” podział ustrojów, uwzględniajacy odrębne ich rodzaje, jako pierwsza, druga i trzecią ligę. Rozumujac przez analogię z ligami piłkarskimi, uzyskiwalibyśmy sytuacje awansu $\mathrm{w}$ ramach jednej $z$ lig, albo awans $z$ niższej do wyższej itd. ${ }^{36}$

\section{Tradycja klasyczna - raz jeszcze}

Tradycja klasyczna „postrzega republikę jako przestrzeń realizacji wspólnego dobra", istotne pozostawało tu również czynne obywatelstwo, poczucie łączności i uczestnictwa oraz „szczególny sposób bycia obywateli, ich sposób postrzegania samych siebie i swojej relacji do wspólnoty politycznej".

Republikańska „rzecz wspólna” nie jest - wedle Stawrowskiego - „jedynie naszą wspólną własnością", upoważniajaca wszystkich obywateli do korzystania zeń. Jest bowiem „ona raczej czymś, co nas wspólnie zobowiazuje i o co należy się wspólnie troszczyć. Res publica to przede wszystkim nasza postawa wobec wspólnoty, postawa, dla której gotowość służby wspólnemu dobru jest sprawa naturalna, oczywista i znajduje się na szczycie naszej hierarchii wartości - wyżej nawet niż własne życie.

Można w tym kontekście cofnąć się aż do Platona.

U Platona, poczacwszy od jego Politei (tłumaczonej na angielski jako The Republic), nacisk został położony na kwalifikacje etyczne oraz intelektualne, nazywane cnotami; dla niego wzorcowa polityka republikańska ${ }^{37}$ to nic innego jak realizacja cnoty sprawiedliwości w skali całej polis.

Platon wierzył, że w takim ustroju republikańskim rządy sprawowane by-

36 Ibidem, s. 150.

37 W wersji poprawionej, w Leges, będaca zarazem ustrojem mieszanym oraz rzadzaca się prawami. 
łyby przez dobrze wyedukowane elity moralno-intelektualne. Mamy tam i elitaryzm $^{38}$, ale o tyle osobliwy, że sprawujący władzę sprawiedliwie pełnia służbę publiczna, dbając od dobro rządzonych obywateli, roztaczając nad nimi opiekę i wypowiadajac się w ich imieniu, reprezentujac ich interesy.

Gdy chodzi o współczesnych polityków, składajacych obietnice wyborcze, to oczywiście chętnie posługują się oni retoryka dobra publicznego, pozostajac w tym najczęściej mało wiarygodni. Dla Platona i Arystotelesa zasadnicze znaczenie ma klasyfikacja ustrojów na prawowite, gdzie celem rządzenia jest realizacja dobra rządzonych i całej wspólnoty, niezależnie od kryterium ilościowego (ile osób te rzady sprawuje) ${ }^{39}$. Mimo położenia nacisku na „konstytucyjne rzady praw" utrzymane pozostaje założenie, iż kluczowa kwestia jest poziom uczciwości i sprawności te prawa realizujacych i nadzorujących:

„Dla każdego jasne jest z pewnością, że chociaż wielkim osiągnięciem jest ustanowienie praw, to jednak jeżeli dobrze urządzone państwo nieodpowiednim władzom powierzy pieczę nad dobrze ustanowionymi prawami, nie tylko żadnej korzyści nie będzie $z$ dobrych praw, lecz staną się one przedmiotem drwin i szyderstwa i największą bodaj szkodę i hańbę ściągną na takie państwo" ${ }^{40}$.

38 Elitaryzm, który może być kojarzony z arbitralnym czy autorytarnym sprawowaniem rządów.

${ }^{39}$ Klasycy greccy byli też realistami uważając, że w praktyce rządzić moga jedynie nieliczni; de facto nawet funkcji prawodawczej bezpośrednio nie może piastować całe społeczeństwo, zaś przyzwolenie na te czy inne regulacje prawne to władza nader wtórna i rzadko istotna.

40 Platon, Prawa, 751b, s. 213.
W kwestii wyłaniania ludzi posiadajacych należyte kwalifikacje, to klasycy nie pochwalali ani losowania, ani wyborów przez lud, lecz najpierw odpowiednie kształcenie i wychowywanie przyszłych elit, jak i rekrutacje przez dotychczasowe środowiska przywódcze.

Tych kluczowych elementów (jak cel rządzenia, publiczne dobro wspólne, podwyższone kwalifikacje etyczno-intelektualne) nie zastępuja „konstytucyjne rządy prawa", gdzie legistyczny formalizm zbliża się do partyjnej „walki na prawa" N. Machiavellego, walki czy to oligarchów, czy demagogów skrywających swe lekceważenie dla dobra publicznego wspólnoty.

\section{Klasyczna tradycja republikańska - potrzebuje przypominania}

Klasyczna tradycja republikańska, chociaż zepchnięta została poza główne nurty myśli nowożytnej, to zachowała pewne wpływy $^{41}$. Ich oznaki widoczne są również w polskim życiu politycznym minionych wieków. To również stanowi asumpt, aby współcześnie, poszukując przesłanek dla ożywienia republikanizmu obywatelskiego, sięgać do pewnych elementów tego dziedzictwa. Szczególnie interesujace byłyby te elementy dawnego republikanizmu, które pozwalają przeciwstawiać się pasywnemu nastawieniu obywateli we współczesnych masowych demokracjach liberalnych.

${ }^{41}$ Również u tzw. „obywatelskich humanistów”, z których część opowiadająca się za perfekcjonizmem i aktywnym uczestnictwem w sprawach publicznych (jak niektórzy komunitarianie - choćby A. MacIntyre), stanowi przeciwwagę dla skrzydła bliższego liberalizmowi. 


\section{Republikanizm klasyczny i nowoczesny wg Pangle'a ${ }^{42}$}

Wolność w klasycznym, Arystotelesowskim rozumieniu republikanizmu oznacza realna możliwość czynnego uczestnictwa w sprawowaniu rządów nad wspólnota, do której przynależymy jako obywatele. Albowiem władza specyficznie polityczna to „rzady wolnych nad wolnymi”, gdzie „nie może rządzić dobrze ten, kto się najpierw nie nauczył słuchać”. „Dobry obywatel” Arystotelesa posiada takie przymioty charakteru, które zakładaja utrwalone dyspozycje do respektowania zarówno prawa, jak i nakazów rządzacych $-z$ jednej strony, a $z$ drugiej zdolność do samorząności i sprawowania tychże rząów (jak zapewne i och rozsąnego krytykowania w debatach publicznych) ${ }^{43}$.

Pangle wszakże słusznie zwraca uwage, iż stronnicy republiki, aby rzeczywiście rządzić, muszą sobie na to zapracować, muszą wyróżniać się, by zasłużyć na wybór do grupy przywódczej w republice; od tej grupy wymaga się podwyższonych kwalifikacji moralnych i intelektualnych. W tym znaczeniu nie ma tu „równości wobec prawa” w tym sensie, żeby nie wymagano niczego więcej jak bycia wylosowanym spomiędzy wszystkich wolnych obywateli. Arystoteles więc, wedle tej wykładni, wyklucza „naiwny egalitaryzm i libertarianizm”, wyznaczając podwyższone standardy wobec pretendentów do sprawowania najwyższych urzędów publicznych. Wysoki prestiż oraz wyższy szacunek należy się ludziom zasłużonym dla sprawiedliwego porządku arystokratycznej

42 T. L. Pangle, Uszlachetnianie demokracji. Wyzwanie epoki postmodernistycznej, tłum. M. Klimowicz, Wyd. Znak, Kraków 1994.

${ }_{43}$ Zob. Arystoteles, Polityka, 1277b 7-16 oraz T.L. Pangle, Uszlachetnianie demokracji..., op. cit., s. $150-51$. republiki. Na zaufanie obywateli trzeba zasłużyć.

$\mathrm{Na}$ tym opieraja się też cnoty obywatelskie, że sama „równość wobec prawa”, w znaczeniu, że się mu podlega na równi - to za mało, aby powstał i trwał porzadek republikański. Może się także zdarzać, choć na zasadzie pewnego „przejściowego odstępstwa", że potrzebne sa „rządy pierwszego wśród równych”, czyli jakieś rządy wyjątkowo predysponowanej w danej sytuacji jednostki, np. króla czy prezydenta.

Aby zasługiwać na udział we władzach publicznych, trzeba wyróżniać się cnotami intelektualnymi oraz moralnymi: wnikliwościa umysłu, praktyczna roztropnościa oraz rozwaga, szlachetnościa charakteru (aristoi), sprawiedliwościa, a nie tylko ambicja i wymownościa. Absolutna rzadkościa jest sytuacja, gdy w danej wspólnocie obywatelskiej tylko jednostka posiada w wysokim stopniu te kwalifikacje. Zatem rządy w klasycznym republikanizmie powinna sprawować prawdziwa arystokracja ${ }^{44}$, ale długofalową kontrolę nad nia sprawuje większość obywateli, przy udziale bezstronnej władzy sędziowskiej. To jednak nie zawsze jest dopełniane i nie zawsze bywa możliwe, gdyż $\mathrm{w}$ republice znajdującej się w dobrym stanie oczekiwane sa cnoty od wszystkich obywateli bez różnicy, a co najmniej większość powinna podsiadać najważniejsze kwalifikacje. Bez tego wolne wybory wyłonia ludzi popularnych, którzy będą działać na szkodę republiki.

Cnoty republikańskie zakładaja współwystępowanie jednocześnie bogatego doświadczenia praktycznego oraz możliwie wysokiego wykształcenia, podnoszacego wrodzone predyspozycje. Innymi słowy, kandydaci na urzędy musza wyróżniać się właściwą skalą wartości

${ }^{44}$ Por. T. L. Pangle, op. cit., s. 152-153. 
i nie stawiać na czele tejże skali korzyści własnych czy swego rodu, czy partykularnego ugrupowania. Wówczas cała wspólnota korzysta $z$ umiejętności ludzi roztropnych i uczciwych.

Oszustwo, zręczne udawanie kogoś, kim się nie jest, przebiegłość, cynizm, zdolność zwodzenia i manipulowania innymi - wszystkie te przymioty, które tak wysoko cenił Machiavelli, stanowia ogromne zagrożenie dla klasycznej republiki! ${ }^{45}$

\section{Konkluzja: nie niwelujmy różnic, nie rozmazujmy konturów!}

Z perspektywy klasycznego republikanizmu, dwuznacznie przedstawia się zawołanie głoszące nadrzędność „rządów prawa”. Dla filozofii cywilizacji, zachowującej ciągłość względem klasycznego rozumienia republikańskości, a więc np. dla Konecznego, zasadniczym będzie, jakie to prawo: publiczne czy prywatne? W jakim stosunku pozostajace do pięciomianu wartości, w tym do dobra i zła, sprawiedliwości i niegodziwości; czy zorientowane na ekspansję militarna, czy nie? Wystarczy być może już chwila namysłu nad kwestia, czy to fizyczna albo ekonomiczna "siła stanowić ma prawo", jak głosza dawni i nowi sofiści (także i ci hobbesowscy, jak Carl Schmitt), aby stało się jasne, iż w takim przypadku to przeważająca w elektoracie większość albo liczni o niskich kwalifikacjach albo oligarchiczna mniejszość (nieliczni spomiędzy) ludzi bogatych stanowić będzie prawo niesprawiedliwe $\mathrm{i} \mathrm{w}$ istocie zgubne dla porządku republikańskiego. Tego

45 Ważne jest, czy obywatele sami posiadaja wystarczające kwalifikacje, aby odgraniczać „arystokrację fałszywa" od autentycznej. Ta pierwsza opiera się na „majątku, nazwisku, prestiżu, dobrym wyglądzie, szczęściu itd.” Zob. T. L. Pangle, op. cit., s. 153 . rozwoju wypadków nie zmieni prosperita imperializmu (z jego zdobyczami i wattpliwymi korzyściami) ani dynamika ekonomicznego rozwoju, opartego na rabunku i pasożytnictwie. A to przecież, u Machiavellego, miało konstytuować „ulepszona republikę rzymska”. Manent ${ }^{46}$ chwali „dynamiczną równowagę...”, jaka miałaby wnosić tego typu myśl neorepublikańska. Ale nie zamazujmy zasadniczych różnic! Może nastawiona na te wszystkie wysokie standardy myśl klasycznego republikanizmu jest wygórowana i trudna do praktycznej realizacji. Lecz czy $z$ tego powodu należy zdegradować ją do jakiejś „republiki rodem $z$ fantazji”, czegoś po prostu niemożliwego do zaistnienia? Występowanie $\mathrm{w}$ roli advocatus diaboli stało się udziałem licznych rzesz autorów opowiadajacych się za „nowoczesnym republikanizmem” i „niskim realizmem”, zapoczatkowanym przez „mistrza $z$ Florencji”. Taki pseudo-republikanizm nie ma mego poparcia i zawsze będę mu przeciwny.

Gdy chwilę pomyślimy o nowych mediach, nośnikach i przekaźnikach informacji, środkach transportu itd., paradygmat republikański musi wydać się jakimś „archaicznym urządzaniem świata", nadającym się do pokazywania w muzeum snów Ludzkości. Jednak gdy tę chwilę nieco wydłużyć, przychodzi refleksja druga i trzecia: ludzka natura pozostaje mniej więcej taka sama i rzeczy kiepskie podszywaja się pod te lepsze, zło pod dobro, podłość pod szlachetność - wciąż tak samo.

\section{Bibliografia}

Arystoteles, Polityka, tłum. L. Piotrowicz, w: idem, Dzieła wszystkie, PWN, Warszawa 2001.

${ }^{46}$ P. Manent, Przemiany rzeczy publicznej, op. cit. 
Cyceron Marcus Tulliuss, $O$ prawach, w: Cyceron [Marcus Tulliuss Cicero], $\mathrm{Pi}$ sma filozoficzne, t. 2, tłum. W. Kornatowski, PWN, Warszawa 1960.

Cyceron, Filipiki. Mowy przeciwko Markowi Antoniuszowi, tłum. K. Ekes, Prószyński i S-ka, Warszawa 2002.

Cyceron, Księgi akademickie, O najwyższym dobru i złu, Paradoksy stoików, Rozmowy Tuskulańskie, tłum. W. Kornatowski, J. Śmigaj, w: Cyceron, Pisma filozoficzne, t. 3, PWN, Warszawa 1961.

Cyceron, O powinnościach [De officcis], tłum. W. Kornatowski, w: idem, Pisma filozoficzne, t. 2, Warszawa 1960.

Cyceron, O starości, O przyjaźni, Topiki, tłum. W. Kornatowski, w: Cyceron, Pisma filozoficzne, t. 4, PWN, Warszawa 1963.

Cyceron, Wybór listów, tłum. G. Pianko, oprac. M. Plezia, Ossolineum, DeAgostini, Wrocław 2004.

Cyceron, Wybór pism naukowych, tłum. $\mathrm{K}$. Wisłocka-Remerowa, Ossolineum, DeAgostini, Wrocław 2004.

Dawson Charles, Tworzenie się Europy, tłum. J.W. Zielińska, Warszawa 2000.

Gładziuk Nina, S. Józefowicz, Republika. Rozważania o przemianach archetypu, Warszawa 1995.

Griffiths Ryan, Republicanism, w:, Encyclopedia of political theory, Mark Bevir (ed.), SAGE, Los Angeles - London New Delhi - Singapore - Washington DC 2010 .

Hobbes Thomas, O obywatelu, tłum. Cz. Znamierowski, w: idem, Elementy filozofii, t. 2, Warszawa 1956.

Kinneging Andreas M., Aristocracy, anti- quity and history. An essay on classicism in political thought, Transaction Publishers, New Brunswick N.J. 1994.

Kinneging Andreas M., Liberty and Virtue: a Ciceronian view, w: Cnoty polityczne - dawniej i obecnie: moralne źródła polityki, red. R. Piekarski, Gdańsk 1997.

Kłoczowski Paweł, Bitwa ksiażek. Konfrontacja Arystotelesa $z$ nowożytna filozofia polityczna, Wyd. Księgarnia Akademicka, Kraków 2007.

Koneczny Feliks, Cywilizacja bizantyńska, „Ostoja”, Krzeszowice 2004.

Koneczny Feliks, O wielości cywilizacyj, Kraków 1935, Komorów 1996.

Koneczny Feliks, Polskie logos a ethos. Roztrzasania o znaczeniu i celu Polski, t. 1-2, Poznań 1921, Komorów 1996.

Krasnodębski Zdzisław, Republikanizm po komunizmie - utopia czy alternatywa?, http: / /omp.org.pl/artykul.php?artykul=299 (dostęp: 8.07.2013).

Legutko Ryszard, Demokracja i republika, http://www.omp.org.pl/artykul. php?artykul=224 (dostęp: 26.07.2013).

Machiavelli Nicolo, Rozważania nad pierwszym pieccioksiegiem historii Rzymu, tłum. K. Żabolicki, Wyd. UW, Warszawa 2009.

MacIntyre Alasdair, After Virtue, drugie wydanie, University of Notre Dame 1984.

Manent Pierre, Rozdz. I: Rzym i Grecy, w: idem, Przemiany rzeczy publicznej. Od Aten do całej ludzkości, tłum. W. Dłuski, Wyd. Europejskie Centrum Solidarności, Gdańsk 2014. 
Mansfield Harvey C., Machiavelli's Virtue, Chicago-London 1996.

Pangle Thomas L., Uszlachetnianie demokracji. Wyzwanie epoki postmodernistycznej, tłum. M. Klimowicz, Wyd. Znak, Kraków 1994.

Pangle Thomas L., Ahrensdorf J., Justice among nations. On the moral basis of power and peace, University Press of Kansas 1999.

Pangle Thomas L., The Spirit of Modern Republicanism. The Moral Vision of the American Founders and Philosophy of Locke, Chicago 1990.

Pettit Philip, The Freedom of the City: A Republican Ideal, [in:] The Good Polity, Alan Hamlin and Philip Pettit (eds.), Blackwell Publishers. Oxford 1989.

Piekarski Romuald, Koncepcja cnót politycznych Machiavellego na tle elementów klasycznej etyki cnót, Wyd. UG, Gdańsk 2007.

Piekarski Romuald, Makiawelizm, patologia ducha, sacrum i polityka. Eseje $z$ filozofii politycznej, Spółdzielczy Instytut Wydawniczy, Sopot 2016.

Piekarski Romuald, Republikanizm, ale jaki... Jakiego republikanizmu nam Polakom potrzeba?, w: idem, Uniwersalizm czy zamaskowana oligarchia: Obawy $i$ nadzieje $w$ obliczu procesów globalizacyjnych, http://janek.uek.krakow.pl/ limes/files/el2(3)2003/rp_limes2(3).pdf.

Piekarski Romuald, Zagadnienie cnót politycznych-zarys problemu, w: R. Piekarski (red.), Czym jest filozofia polityki?, Gdańsk 1999.
Pietrzyk-Reeves Dorota, Ład Rzeczypospolitej. Polska myśl polityczna XVI wieku a klasyczna tradycja republikanska, Księgarnia Akademicka, Kraków 2012.

Pietrzyk-Reeves Dorota, O pojęciu "Rzeczpospolita” (res publica) $w$ polskiej myśli politycznej XVI wieku, "Czasopismo Prawno-Historyczne" 2010, t. LXII, z. 1, https://repozytorium.amu.edu.pl/ bitstream/10593/1992/1/Pietrzyk-Reeves.pdf (dostęp: 24.09.2016).

Platon, Prawa, tłum. M. Maykowska, PWN, Warszawa 1960.

Pocock John G.A., The Machaivellian Moment. Florentine Political Thought and the Atlantic Republican Tradidtion, Princeton 1975.

Pocock John G.A., Virtus, rights and manners: A Model for Historians of Political Thought, „Political Theory” 1981, No. 3.

Polibiusz, Dzieje, t. 1, tłum. S. Hammer, Ossolineum - DeAgostini, Wrocław 2005.

Rahe Paul A., Republics Ancient and Modern: Classical Republicanism and the American Revolution, University of North Carolina Press, Chapel Hill-London 1992.

Receptions of Cicero, w: C. Steel (red.), The Cambridge companion to Cicero, Cambridge University Press, New York 2013.

Skinner Quentin, The foundations of modern political thought, t. 1, The Renaissance, Cambridge 1979. 
Skinner Quentin, Wolność przed liberalizmem, tłum. A. Czarnecka, Wyd. Naukowe UMK, Torun 2013.

Stawrowski Zbigniew, O republice i postawie republikańskiej. Część 1: Dziedzictwo Platona, „Rzeczy Wspólne” 2010, nr 1 .

Sullivan Vickie B., Machiavelli, Hobbes, and the Formation of a Liberal Republicanism in England, New York 2004.
Toynbee Arnold, Studium historii. Skrót dokonany przez D.C. Somervella, tłum. i przedm. J. Marzęcki, PiW, Warszawa 2000.

Viroli Maurizio, Uśmiech Machiavellego. Biografia. tłum. K. Żaboklicki, wyd. W.A.B., Warszawa 2006. 